\title{
Kebersahajaan Ekspresi dan Makna Karya Sastra Mustofa Bisri
}

\author{
Redyanto Noor \\ Fakultas Ilmu Budaya, Universitas Diponegoro \\ redyanto_noor@yahoo.com
}

\begin{abstract}
The simplicity of the expression and meaning of literary works of Mustofa Bisri is seen in the simplicity of the use of its poetic and aesthetic. The simplicity of the poetic and aesthetic means includes the elements of the structure of literary works and the manner in which they are expressed. The elements of the structure of literary works include typography, sounds, diction, images, and meaning. The simplicity of typography is seen in the freedom of the traditional ties and conventions of the theoretical structure of the poetical visualization. The simplicity of the sound is seen in the beauty, fusion, harmony, wholeness, and simplicity of its orchestration so it is more beautiful if Gus Mus's literary works are spoken. The simplicity of diction is seen in its attachment by clichés, classics, and bombastic, but in the election of words that are normally used to conversing and joking in everyday communication. The simplicity of his imagination is seen in the picture of wishful passage in and around the dwelling; next door neighbors, food stalls, markets, and everyday events: working, watching television, worshiping. The simplicity of meaning is seen in the reasonableness and calm it produces, namely the ability to dampen turmoil, not only the turmoil of body and soul, but also social unrest.
\end{abstract}

Keywords: expression, meaning, simplicity, literary structure, depth of meaning

\section{Intisari}

Kebersahajaan ekspresi dan makna karya sastra Mustofa Bisri terlihat pada kesederhana penggunaan sarana puitika dan esktetikanya. Kesederhanaan sarana puitika dan estetika itu mencakup unsur-unsur struktur karya sastra dan cara pengungkapannya. Unsur-unsur struktur karya sastra itu meliputi tipografi, bunyi, diksi, imaji, dan maknanya. Kesederhanaan tipografi terlihat pada kebebasan dari ikatan tradisi dan konvensi struktur visualisasi puisi yang teoretis. Kesederhanaan bunyi terlihat pada keindahan, perpaduan, keselarasan, keutuhan, dan kebersahajaan orkestrasinya sehingga lebih indah apabila karya sastra Gus Mus dilisankan. Kesederhanaan diksi terlihat pada ketakterikatannya oleh kata-kata klise, klasik, dan bombastis, tetapi pada pemilihan kata-kata sewajarnya yang biasa dipakai bercakapcakap, bergurau, berseloroh dalam komunikasi sehari-hari. Kesederhanaan imajinya terlihat pada gambaran angan-angan yang lalu-lalang di sekitar tempat tinggal; tetangga sebelah rumah, warung makan, pasar, serta peristiwa sehari-hari: bekerja, menonton televisi, beribadah. Kesederhanaan makna terlihat pada kewajaran dan ketenangan yang ditimbulkannya, yakni kemampuan meredam gejolak, tidak saja gejolak jiwa dan raga, tetapi juga gejolak sosial.

Kata kunci: ekspresi, makna, kebersahajaan, struktur sastra, kedalaman makna 


\section{"Cintamu"}

bukankah aku sudah mengatakan kepadamu, kemarilah rengkuh aku dengan sepenuh jiwamu datanglah aku kan berlari menyambutmu tapi kau terus sibuk dengan dirimu kalaupun datang kau hanya menciumi pintu rumahku

("Cintamu", A. Mustofa Bisri)

\section{Pendahuluan}

Tidak banyak orang percaya bahwa sastra yang baik adalah sastra yang tidak sulit. Sastra yang baik adalah sastra yang dapat membuat pembaca menyukainya, karena mengerti dan merasakan sentuhan-sentuhan makna pada batinnya sehingga tidak kuasa mengelak untuk selalu mengingatnya. Sastra yang tidak sulit adalah sastra yang tidak gelap, tidak aneh-aneh, tidak "ribet" dan rumit. Karena materi dan medium yang membangun struktur dan makna sastra adalah bahasa, maka sastra yang baik ditandai oleh bahasa yang tidak gelap, tidak aneh-aneh, tidak "ribet" dan rumit. Kalau struktur dan makna sastra dibangun oleh bahasa melalui tahap-tahap visualisasi tipografi, bunyi, diksi, imaji, dan makna, maka tiap tahap itu mestinya terbaca dan terasa tidak gelap, aneh, "ribet", dan rumit. Negasi yang lazim terhadap kegelapan, keanehan, keruwetan, serta kerumitan itu adalah kesederhanaan, kewajaran, kebersahajaan.

Pada penggalan puisi di atas tidak ada kata-kata yang tidak digunakan dalam percakapan sehari-hari? Setiap kata dalam penggalan sajak di atas tiap hari barangkali lebih dari sepuluh kali digunakan untuk bercakap-cakap. Apakah kata-kata itu mengurangi kepuitisan bahasa puisi tersebut? Sesungguhnya jika penyair dan pembaca merasa cukup dengan kata "aku", apa gunanya kata "beta", "hamba", dan sebagainya; jika merasa cukup dengan kata "jiwa", apa gunanya kata "sukma", "atma", dan sebagainya. Jadi, bagi sastra kebersahajaan itu penting, tidak saja dalam hal bahasa, struktur, imaji, dan makna, tetapi juga pesan yang dikandungnya. 


\section{Pembahasan}

\section{Sastra Gus Mus: Tipografi yang Bersahaja}

Nyaris seluruh sastra karya Gus Mus, terutama puisi-puisinya, tidak terikat oleh tradisi dan konvensi struktur visualisasi puisi yang teoretis. Tidak ada periodisitas dan korespondensi antarbaris, tidak ada periodisitas dan korespondensi antarbait, bahkan sebenarnya periodisitas dan korespondensi itu sendiri tidak ada. Tidak satu pun sastra karya Gus Mus, baik cerpen maupun puisi, yang tipografinya (susunan baris, bait, kata, kalimat, paragraf) aneh, "nyleneh", atau sekadar tampil beda. Dalam membaca sastra, kesederhanaan tipografi itu memudahkan tercapainya keberterimaan, dan keberterimaan itu ujungnya adalah keterpahaman.

Pada sastra karya Gus Mus, terutama puisi-puisinya, kesederhanaan tipografi menjadikan pembaca mudah memahami karena satuan tipografinya bukan satuan baris atau satuan bait, melainkan satuan sintaksis. Jadi, pembaca tidak perlu repot merangkai kata demi kata hingga menemukan kalimat yang lengkap, karena sebenarnya puisi-puisi itu sendiri sudah dinyatakan dalam susunan kalimat lengkap, meskipun seringkali tidak terdapat tanda baca, atau tanda-tanda kebahasaan yang lain.

\section{Sastra Gus Mus: Bunyi yang Bersahaja}

Dalam hal bunyi, sastra yang baik adalah sastra yang memperdengarkan orkestrasi bunyi selaras dan berkomposisi merdu jika dilisankan, baik cerita fiksi maupun puisi. Orkestrasi bunyi yang selaras dan berkomposisi adalah keseimbangan dan kesesuaian antara jenis bunyi dan nuansa suasana yang ditimbulkannya. Bunyi-bunyi cacophony yang berat dan dalam akan menciptakan nuansa kengerian: kasar, keras, berangas. Sebaliknya, bunyi euphony yang ringan dan dangkal akan menciptakan nuansa keapatisan: acuh tak acuh, pesimis, putus asa.

Jika dilisankan, rangkaian bunyi pada sastra karya Gus Mus memperdengarkan orkestrasi bunyi sangat simponis. Tidak ada dominasi bunyi-bunyi berat pada vokal dan konsonan $(\mathrm{o}, \mathrm{u}, \mathrm{b}, \mathrm{d}, \mathrm{g}, \mathrm{h})$ atau bunyi-bunyi ringan pada vokal dan konsonan (a, i, e, k, p, t, s, r). Bunyi-bunyi itu semuanya dalam sastra karya Gus 
Mus memainkan perannya secara sederhana, seperlunya saja. Sebagaimana konsep filsafat seni yang dikemukakan Santayana bahwa keindahan itu terletak pada keselarasan, keutuhan, dan kesederhanaan. Dalam hal bunyi, pada sastra karya Gus Mus filosofi itu terpenuhi. Oleh sebab itu, saya menduga bahwa meresapi pembacaan sastra karya Gus Mus lebih indah dibanding mendengarkan langsung ceramahnya. Suasana sunyi-senyap meresapi bunyi pada kata-kata dalam pembacaan cerpen dan puisi Gus Mus memberi ketentraman dan perenungan berbeda dibanding suasana hiruk-pikuk ribuan umat mengikuti tauziah Gus Mus.

\section{Sastra Gus Mus: Diksi yang Bersahaja}

Bahasa Indonesia adalah salah satu bahasa yang paling banyak memiliki derivasi dan padan kata dibanding bahasa lain yang ada di dunia. Misalnya, kata mati dalam bahasa Indonesia memiliki lebih dari sepuluh padan kata (mangkat, wafat, berpulang, gugur, meninggal, tewas, maut, modar, koit, dead, dood, dan sebagainya). Oleh sebab itu, dalam sastra, memilih kata bukan persoalan sederhana. Memilih kata untuk menulis sastra berbeda dengan memilih kata untuk menulis berita atau menulis surat. Memilih kata untuk menulis sastra tidak sekadar mencermati kata berdasar ketepatan makna denotatifnya, melainkan perlu memperhitungkan pertaliannya dengan makna konotatif, asosiatif, sugestif, dan sebagainya. Bagi sastra, kata yang baik adalah kata yang memiliki kekuatan mengekspresikan gagasan pengarang sekaligus kekuatan membangun suasana estetik (sebal, muak, geram, gemas, cemas, haru, pilu, ragu, rindu, tentram, tenang, sejuk, adhem). Membangun suasana estetik tidak berarti harus dengan kata-kata klasik, klise dan bombaste. Kata-kata sewajarnya yang biasa kita pakai untuk percakapan sehari-hari dalam ketepatan fungsinya akan berubah menjadi dahsyat dalam sastra. Perhatikan penggalan puisi berikut,

\section{"Perkenankanlah Aku MencintaiMu"}

perkenankanlah aku mencintaimu semampuku menyebut-nyebut namamu dalam kesendirian pun lumayan berdiri di depan pintumu tanpa harapan 
kau membukakannya pun terasa nyaman sekali-kali membayangkan kau memperhatikanku pun cukup memuaskan perkenankanlah aku mencintaimu sebisaku

("Perkenankanlah Aku Mencintaimu", A. Mustofa Bisri)

Menyatakan cinta pada Tuhan bukan sikap bermain-main, berseloroh. Tuhan itu hebat dan dahsyat, maka tradisi dan norma berpikir kita tentang Tuhan juga harus hebat dan dahsyat. Itulah sebabnya, ketika kita menyatakan kehebatan dan kedahsyatan cinta pada Tuhan yang terjadi justru kita kelelahan memilih kata-kata yang paling hebat dan dahsyat. Akibatnya, bisa jadi pernyataan cinta itu mengalami degradasi makna. Perhatikan penggalan puisi berikut,

Ya Allah, Engkau adalah pelabuhan hatiku

Ya Rob, Engkau adalah tambatan suksmaku

Engkau adalah syahbandar cintaku

Engkau samudera puncak muara asaku

Mencermati penggalan di atas, dari sisi semantik kebahasaan (denotasi, konotasi, asosiasi, sugesti), maka apa bedanya Tuhan dengan Tanjung Emas, Tanjung Priok, Tanjung Perak, dan dermaga-dermaga lainnya. Puisi Gus Mus tidak memerlukan kata-kata hebat dan dahsyat seperti itu. Kata-kata sewajarnya yang biasa kita pakai bercakap-cakap, bergurau, berseloroh dalam sastra karya Gus Mus sudah bermakna lebih dari cukup.

\section{Sastra Gus Mus: Imaji yang Bersahaja}

Imaji yang baik pada sastra adalah kekuatan sastra itu mengembarakan angan-angan kita mencapai katarsis. Puncak katarsis itu teralami ketika kita merasakan kenikmatan dalam cengkeraman bermacam-macam perasaan (sebal, muak, geram, gemas, cemas, gundah, haru, pilu, ragu, rindu, tentram, tenang, sejuk, adhem). Melalui bahasa, imaji sastra memberi sugesti atau bahkan memprovokasi pikiran dan perasaan kita lepas dari kesadaran, sebagaimana kesadaran cakrawala-harapan (Jauss: horizonexpectations) umumnya para pembaca sastra. Membaca sastra karya Gus Mus tidak perlu berharap terlalu banyak memperoleh imaji meluap-luap yang melambungkan angan-angan membubung ke surga; atau membenamkan angan-angan tenggelam ke 
dasar neraka, niscaya sia-sia. Sebab, imaji sastra karya Gus Mus hanya lalu-lalang di sekitar tempat kita berada; tetangga sebelah rumah tempat kita bergunjing, warung tempat kita biasa "ngopi", pasar tempat kita berlagak humanis, kaca televisi sebagai cermin tempat melihat wajah kita sendiri, bahkan di dalam rumah sendiri tempat kita biasa mengukur kualitas rumah orang lain. Perhatikan penggalan cerita pendek berikut.

"Iseng"

Di hotel, aku masih sempat subuhan sebelum kembali tidur.

Habis tidur bersantai-santai sambil bermain-main remot-kontrol. Mencari acara tv yang cocok; kadang-kadang malah bingung; terlalu banyak yang menarik untuk ditonton. Asyiknya karena tak perlu rebutan dengan anakisteri seperti di rumah. Nontonnya pun bisa los, sepenuh perhatian. Mau ketawa, mau tepuk tangan, mau mengumpat tak perlu ditahan-tahan dan tak perlu sungkan-sungkan. Tapi setelah pilih saluran sana, saluran sini, akhirnya aku capek sendiri.

('Iseng", Gus Mus)

Penggalan cerita di atas menggambarkan realitas harfiah, keadaan yang bisa dialami oleh siapa pun. Kita tidak merasa perlu menafsirkan secara estetis apa makna keadaan itu, karena kita mengalaminya sehari-hari. Itulah sebabnya, kita lupa bahwa rebutan saluran tv itu sesungguhnya persoalan serius tentang toleransi; kebebasan ketawa, tepuk tangan, mengumpat itu sesungguhnya masalah serius tentang egoisme; keletihan memilih saluran tv itu sesungguhnya persoalan serius tentang keserakahan.

\section{Sastra Gus Mus: Makna yang Bersahaja}

Bersahaja artinya tidak berlebihan. Tidak berlebihan sama dengan tidak ngeyel. Tidak ngeyel sinonimnya tidak "ngotot". Tidak "ngotot" wujudnya tidak mengandalkan kekuatan fisik, karena kekuatan fisik pelampiasannya adalah kecenderungan destruktif, dan kecenderungan destruktif ujungnya adalah chaos. Maka, yang bersahaja dengan sendirinya akan meredam gejolak, tidak saja gejolak jiwa dan raga, 
tetapi juga gejolak pada kerumunan massa. Kebersahajaan sastra karya Gus Mus menunjukkan kewajaran pada semua unsur kesastraannya. Tidak ada yang berlebihan pada tipografinya, bunyinya, kata-katanya, pencitraannya, dan makna yang dikandungnya. Maka, membaca sastra karya Gus Mus tidak perlu mengernyitkan dahi berpikir keras, tidak perlu menahan nafas memusatkan konsentrasi, tidak perlu mengepalkan tinju menghimpun emosi. Membaca sastra karya Gus Mus tidak perlu berlebihan, ngeyel, atau "ngotot", karena sastra karya Gus Mus tidak akan menjadikan kita kuat, pemberani, dan sakti. Sastra karya Gus Mus, sebaliknya, menjadikan kita berpandang bening, berperasa lembut, dan berpikir jernih. Artinya, menjadikan kita manusia sewajar-wajarnya manusia.

\section{Simpulan}

Segala sesuatu yang berlebihan pada puncaknya akan kembali kepada kewajaran; begitu pula yang berkekurangan, pada titik nadirnya akan kembali kepada kewajaran. Maka, kewajaran itulah yang tidak berubah, kewajaran yang abadi. Kalau sastra karya Gus Mus saya katakan bersahaja, maka sastra karya Gus Mus bisa jadi abadi. Namun demikian, keabadian itu hanya akan tetap melekat pada sastra itu sendiri kalau khalayak pembaca tidak memiliki kesadaran dan niat melakukannya dalam kehidupan sehari-hari. Itulah sebabnya, saya berpikir tidak ada ruginya jika sejenak kita mengingat sastra-sastra karya Gus Mus sebelum melakukan apa pun: berangkat beribadah, bekerja, belanja, nonton bola, kampanye, unjuk rasa, bahkan berkelahi dan tawuran sekali pun.

\section{Daftar Pustaka}

Bisri, A. Mustofa. 2008. Lukisan Kaligrafi (cetakan ke-3). Jakarta: Kompas Media Nusantara.

Ellis, John M. 1974. The Theory of Literary Criticism. Los Angeles: California University Press. 
Fowler, Roger. 1981. Literature as Social Discourse: The Practice of Linguistics Criticism. London: Bastford Academic and Educational Ltd.

Pradopo, Rachmat Djoko. 1990. Pengkajian Puisi. Yogyakarta: Gadjah Mada University Press.

Scholes, Robert. 1969. The Nature of Narrative. London: Oxford University Press.

Traugott, Elizabeth. 1980. The Study of Linguistics of Literature. London: Oxford University Press 